\title{
Pesticide contaminants in Clarias gariepinus and Tilapia zilli from three rivers in Edo State, Nigeria; implications for human exposure
}

\author{
Lawrence I Ezemonye ${ }^{1}$, Ozekeke S Ogbeide ${ }^{1 *}$, Isioma Tongo ${ }^{1}$, Alex A Enuneku and Emmanuel Ogbomida ${ }^{2}$
}

\begin{abstract}
The concentrations of 16 pesticides residues (alpha BHC, gamma BHC (lindane), beta BHC, Heptachlor, Aldrin, Heptachlor Epoxide, Endosulfan I, Dieldrin, Endrin, Endosulfan II, 4, 4 DDT, Endosulfan Aldehyde, Endosulfan sulfate, Atrazine, Phosphomethylglycine and Carbofuran) in two fish species (Tilapia zilli and Clarias gariepinus) from selected rivers (Illushi, Owan and Ogbesse) in Edo State, Nigeria was investigated and the associated human health risks from the consumption of contaminated fishes was also determined. Fish species were collected for a period of 18 months, and pesticides analyses was carried out using Gas Chromatography (GC) equipped with Electron Capture Detector (GC-ECD). The distribution of pesticide residues was more in the tissues of Clarias gariepinus (5.53-9.98 $\mu \mathrm{g} / \mathrm{g}$ wet weight) than Tilapia zilli (3.49- $4.98 \mu \mathrm{g} / \mathrm{g}$ wet weight), while the most dominant pesticide in all the stations and all fish species was the persistent organochlorine; $\Sigma \mathrm{BHC}$. Furthermore, the estimated dose for alpha BHC, beta BHC, Endosulfan Aldehyde, DDT, Endosulfan I, Endosulfan II, gamma BHC, Heptachlor, Endosulfan sulfate, Atrazine, Phosphomethylglycine and Carbofuran, do not pose direct hazard to human health since values were lower than the reference dose and Hazard quotient $(\mathrm{HQ})$ were lower than toxic threshold of 1. However, estimated dose for, Heptachlor epoxide, Dieldrin, Endrin and Aldrin exceeded the reference dose and were higher than toxic threshold indicating a potential toxicity in humans.
\end{abstract}

Keywords: Pesticides; Clarias gariepinus; Tilapia zilli; Dietary intake; Health risk; Exposure assessment

\section{Background}

The need to produce a greater quantity and quality of food by pest control has resulted in the intensive use of pesticides (Chaverri et al., 2000). This has led to tremendous benefits in the area of agriculture, forestry, public health, and domestic sphere and has also resulted in an economic boom. This scenario has made pesticide an indispensable tool in agricultural production to the extent, one-third of the agricultural products are produced using pesticides of various sorts (Liu et al., 2002). Despite these overwhelming credits of pesticides use, there has been serious health implications to man and his environment accrued from the use of pesticides. These health implications range from the potential risks to human health from both

\footnotetext{
* Correspondence: oze_ogbe@yahoo.com

${ }^{1}$ Ecotoxicology and Environmental Forensics Laboratory, University of Benin, Benin City, Edo State, Nigeria

Full list of author information is available at the end of the article
}

occupational and non-occupational exposures, the death of farm animals and alteration of the local environment (Hossain et al. 2013). Other effects include; immunologic, teratogenic, carcinogenic, reproductive and neurological problems (Babu et al., 2005). Because of these health implications, the use of most classes of pesticides have been banned in developed and some developing countries (including Nigeria) especially the organochlorines (Ize-Iyamu et al., 2007). Inspite of this ban, pesticides especially organochlorines are still major pollutants in Nigerian waters because of the weak enforcement program on the usage of pesticides (Olatunbosun et al., 2011; Upadhi and Wokoma, 2012; Williams, 2013; Ezemonye et al. 2008a, Ezemonye et al., 2008b, Ezemonye et al., 2009; Ize-Iyamu et al., 2007; Adeboyejo et al., 2011; Okeniyia et al., 2009; Adeyemi et al., 2011).

\section{Springer}


Food consumption has been identified as an important route of human exposure to pesticides with concentrations of pesticides in fish leading to several health concerns, particularly for high-risk population groups, such as pregnant women and children (USEPA, 1998; Jaing et al. 2005). Although the presence of trace levels of these pesticides in food is considered as an indication that contamination has occurred, the risk of adverse health effects also depends on their concentration, frequency of contact and duration of exposure (Jiang et al., 2005). Therefore, assessing the health risk of pesticide exposure involves the use ecological risk assessment models (ERAs). ERA is a process of assessing the ecological health of species, populations, communities and ecosystems due to pesticide exposure (Hoffman et al., 2003). This assessment is necessary because of the tendency of pesticides to accumulate and persist in body tissues, leading to acute or chronic health effects (Pardío et al., 2012).

Assessing Human Health risk involves the use of food consumption data that have been established for a country (Jiang et al., 2005), body weight estimates and acceptable daily intake (ADI) or reference dose set by various regulatory bodies. FAO defines "ADI" of a chemical as the daily intake which, during an entire lifetime, appears to be without appreciable risk to the health of the consumer (WHO, 1997). In recent times, researchers have begun to estimate the risk posed to humans via the consumption of contaminated foods stuffs. Several studies including; Jiang et al. (2005), Gavor et al. (2013), Yohannes et al. (2013), Darko and Akoto (2007), Andoh et al. (2013), Fianko et al. (2011) have reported potential human health risk from the consumption of contaminated food. In Nigeria, there is the dearth of data on the concentration of pesticide residues in various water bodies, while information on the human health effects associated with consumption of aquatic organisms from the polluted water bodies is nonexistent to the best of the author's knowledge (Ize-Iyamu et al., 2007; Ezemonye et al., 2008a,b and Okoya et al., 2013).

This study was conducted in order to assess the potential health risks associated with the consumption of two common fish species contaminated with pesticide residues, obtained from three rivers in Edo State.

\section{Methods}

\section{Study area and sample collection}

The rivers selected were Illushi River (N: $06^{\circ} 45^{\prime} 40^{\prime \prime}$; E: $005^{\circ} 46^{\prime}$ 07.4"), Owan River (N: 06 39' 59.8”; E: $006^{\circ} 36^{\prime}$ $\left.34.2^{\prime \prime}\right)$ and Ogbesse river (N: $06^{\circ} 45^{\prime} 3.7^{\prime \prime}$; E: $005^{\circ} 34^{\prime}$ 03.2") (Figure 1). A total of 54 samples of Clarias gariepinus and Tilapia zilli each were simultaneously collected for this study. Sampling period lasted for 18 months (January 2012 to June 2013).

\section{Extraction of pesticide residues in fish samples}

A simple, rapid solvent extraction method was used to determine total lipids in each fish tissue based on the method described by Randall et al. 1998 and lipid normalized concentrations were obtained using the ratio between pesticide concentration in tissue and lipid fraction in the tissue.

The frozen composite edible portions of tissue samples for each species (Clarias gariepinus and Tilapia zilli) were used for extraction based on the method described by Steinwandter (1992). $25 \mathrm{~g}$ of the samples was inserted into a homogenizer cup, and $100 \mathrm{ml}$ of acetone was added. The sample was homogenized for 20 minutes at $100 \mathrm{rpm}$. The sample was further mixed with $5 \mathrm{~g}$ of anhydrous sodium sulphate. Extraction was done using a soxhlet extraction for approximately 20-25 minutes using dichloromethane and $\mathrm{n}$ hexane mixture. The resulting extract was dissolved with hexane and re-concentrated to 1 to $3 \mathrm{ml}$ (USEPA, 2004).

\section{Gas chromatographic (GC) analysis}

The cleaned up extracts were analyzed for pesticides ( $\alpha$ BHC, $\gamma-$ BHC, $\beta$ - BHC, Heptachlor, Heptachlor Epoxide, Aldrin, Dieldrin, Endrin, 4,4 DDT, Endosulfan I, Endosulfan II, Endosulfan aldehyde, Endosulfan sulfate, Atrazine, Phosphomethylglycine and Carbofuran). Results were obtained using a Hewlett-Packard $(h p) 5890$ Series II equipped with 63Ni Electron Capture Detector (ECD) of activity $15 \mathrm{mCi}$ with an auto sampler. The chromatographic separation was done using a VF-5 ms of $30 \mathrm{~mm}$ capillary column with $0.25 \mathrm{~mm}$ internal diameter and $0.25 \mu \mathrm{m}$ film thicknesses and equipped with $1 \mathrm{~m}$ retention gap $(0.53 \mathrm{~mm}$, deactivated). The GC conditions were as follows: The oven temperature programme: Initial temperature was set at $60^{\circ} \mathrm{C}$ for $2 \mathrm{~min}$ and ramped at $25^{\circ} \mathrm{C} / \mathrm{min}$ to $300^{\circ} \mathrm{C}$ for $5 \mathrm{mins}$ and allowed to stay for $15 \mathrm{~min}$ giving a total run time of $58 \mathrm{~min}$. The injector setting was a pulsed spit less mode with a temperature of $250^{\circ} \mathrm{C}$ at a standard pressure. The injection volume was $1.5 \mathrm{ml}$. The detector temperature was $320^{\circ} \mathrm{C}$ (held for 5 minutes), Helium was used as a carrier gas while Nitrogen gas $\left(\mathrm{N}_{2}\right)$ was used as the makeup gas, maintained at a constant flow rate of $29 \mathrm{ml} / \mathrm{min}$.

The efficiency of the analytical method (the extraction and clean-up methods) was determined by recoveries of an internal standard. Peak identifications were conducted by comparing the retention time of standards and those obtained from the extracts. Concentrations were calculated using a four-point calibration curve. Method detection limits (MDLs) ranged from $0.01 \mu \mathrm{g} / \mathrm{g} /$ $\mathrm{dw}$ for pesticides in biota.

\section{Health risk estimation}

To assess the risk of pesticide contained in each fish species on consumers, the guide- lines for potential risk 


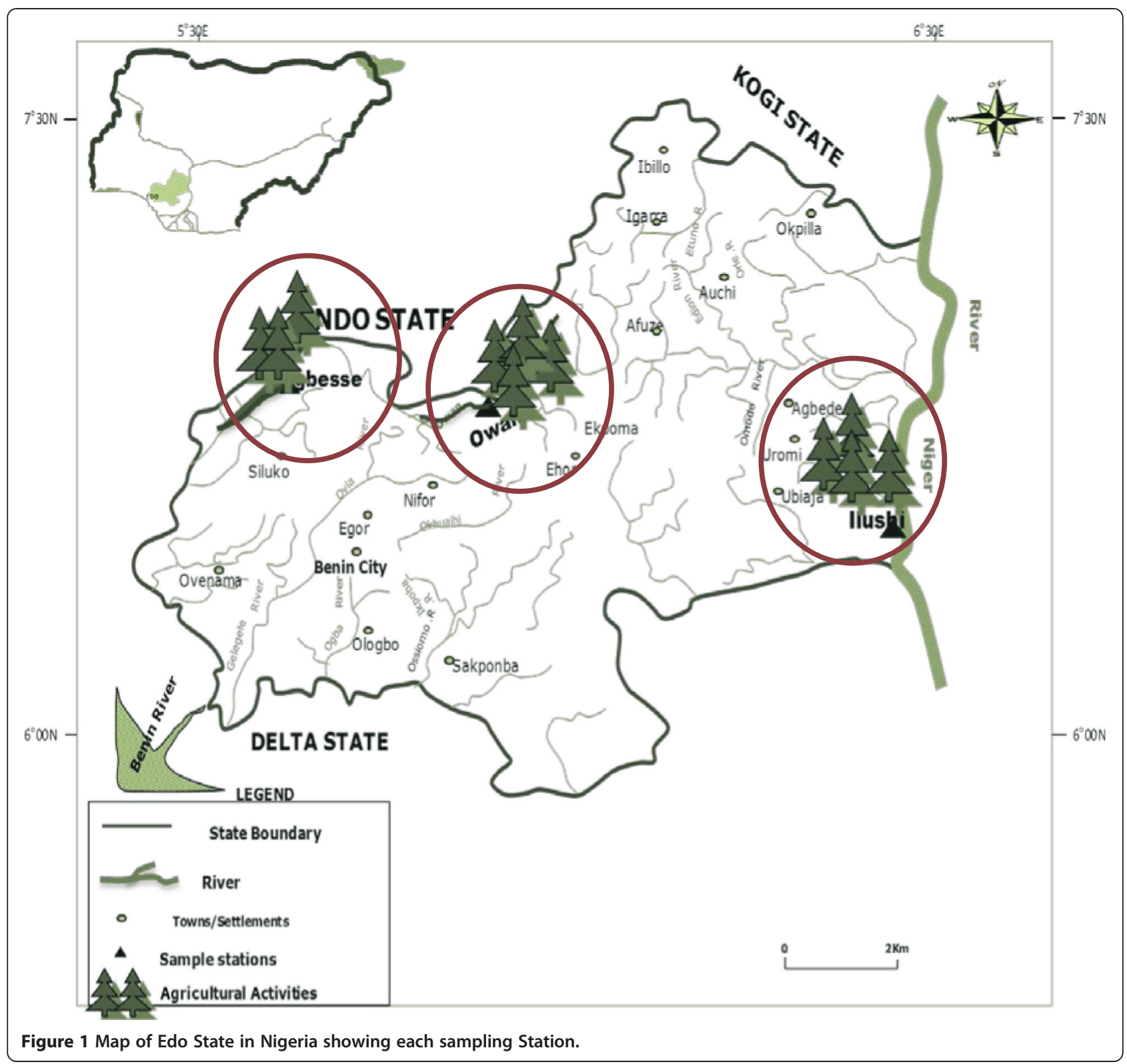

assessment drawn up by the US EPA were used. The reference dose (RfD) of each pesticides is the exposure that is likely to be without an appreciable risk of deleterious effects and was provided by the US EPA (USEPA, 2006). Based on estimated average daily intake (EADI, with Eq. (1)), hazard quotients (HQ, with Eq. (2)) were calculated to estimate the non-cancer risks of pesticide exposure.

\section{Estimated average daily intake (EADI)}

The estimated Average Daily intake (EADI) was found by multiplying the average/ mean residual pesticide concentration $(\mu \mathrm{g} / \mathrm{ww})$ by the fish consumption rate (Kg/day).
EADI $(\boldsymbol{\mu g} / \mathbf{k g} / \mathbf{d a y})=\frac{\text { Residual concentration } \times \text { Food consumption } /}{\text { Body weight. }}$

(WHO, 1997; Fianko et al., 2011),

\section{Hazard quotient (HQ)}

Hazards quotients were obtained by dividing the EADI by their corresponding reference dose (RfD)

$$
\text { Hazard Quotient }=\frac{\text { Estimated Average Daily Intake }}{\text { Reference Dose }}
$$

(WHO, 1997; Fianko et al., 2011), 
The food and agricultural organization (FAO 2011) quotes the per capita consumption of fishes in Nigeria as $9 \mathrm{~kg}$. While body weight was set at $70 \mathrm{~kg}$ for adult population group.

\section{Results}

Analyses showed levels of pesticides residues in 40 samples of Clarias gariepinus and 45 samples of Tilapia zilli (Illushi River), 49 samples of Clarias gariepinus and 48 samples of zilli (Owan River) in Edo State. These findings are summarized in Tables 1 and 2 respectively. The concentration profile of pesticides in each fish species is also presented in Figure 2. It was observed that all pesticides residues detected showed higher concentrations in Clarias gariepinus than Tilapia zilli with beta BHC having the highest concentration $1.67 \& 0.93 \mu \mathrm{g} / \mathrm{g}$ ww respectively. In all the rivers sampled, total pesticide residues was observed to be more in the tissues of Clarias gariepinus (5.53-9.98 $\mu \mathrm{g} / \mathrm{g} \mathrm{ww}$ ) than Tilapia zilli (3.49- $4.98 \mu \mathrm{g} / \mathrm{g} \mathrm{ww})$. However there was no significant difference between concentrations of pesticide residues in Clarias gariepinus and Tilapia zilli $(\mathrm{p}>0.05 ; \mathrm{F}=3.23$ ) in each of the river. Spatial variation showed that Ogbesse River had the highest concentration of pesticide residues in both fish species when compared with Owan and Illushi Rivers (Figure 3). The Organochlorine pesticide beta BHC was the most dominant pesticide, having the highest mean concentration $(0.93 \mu \mathrm{g} / \mathrm{g} w \mathrm{w}$ and $1.67 \mu \mathrm{g} / \mathrm{g} \mathrm{ww})$ and percentage distribution (49\% each) in Clarias gariepinus and Tilapia zilli respectively (Figure 4 and 5).

\section{Dietary intake levels}

The Estimated Acceptable Daily Intake (EADI) of pesticides in Clarias gariepinus and Tilapia zilli for adult population in Edo State is presented in Table 3. Consumptions rates of fishes in Nigeria were obtained from FAO statistics book (FAO, 2011). Risk estimations in Tilapia zilli showed that Heptachlor epoxide and Aldrin exceeded the reference dose and toxicity threshold level (1). While in Clarias gariepinus, Heptachlor epoxide, Aldrin, Dieldrin and Endrin exceeded the reference dose and toxicity threshold level (1) (Figure 6).

\section{Discussion}

The presence of pesticide residues in Clarias gariepinus and Tilapia zilli obtained from Illushi, Owan and Ogbesse rivers is an evidence of bioconcentration (from water via gills and epithelial tissues) and bioaccumilation (through water and food, leading to biomagnification in different organisms) of pesticides from the surrounding environment (Murty 1986). The levels and occurrence of residues in fish samples seem to be governed by feeding mode, age and mobility of the biota, consequently, higher concentrations of pesticide residues oberved in Clarias gariepinus may be attributed to the feeding mode of the fish (Mwevura et al., 2002). Furthermore, Biego et al. (2010), states that Claris gariepinus habitates the level of sediments where it gets most of its food, hence the likely hood of exposure to pesticides. Apart from the entry of pesticides through bioconcentration (via water) in to Clarias gariepinus, they are bottom

Table 1 Mean concentration (ug/gww) of pesticide residues in Clarias gariepinus

\begin{tabular}{|c|c|c|c|c|c|c|c|c|c|c|c|c|}
\hline \multirow{3}{*}{$\frac{\text { Pesticides }}{\text { alpha - BHC }}$} & \multicolumn{4}{|c|}{ ILLUSHI } & \multicolumn{4}{|c|}{ OGBESSE } & \multicolumn{4}{|c|}{ OWAN } \\
\hline & \multicolumn{2}{|c|}{ Mean \pm Std. D. } & \multicolumn{2}{|c|}{ Range } & \multicolumn{2}{|c|}{ Mean \pm Std. D. } & \multicolumn{2}{|c|}{ Range } & \multicolumn{2}{|c|}{ Mean \pm Std. D. } & \multicolumn{2}{|c|}{ Range } \\
\hline & 1.48 & \pm 2.71 & 0 & 8.90 & 1.86 & \pm 1.85 & 0 & 7.30 & 1.16 & \pm 2.05 & 0 & 6.50 \\
\hline gamma-BHC & 0.68 & \pm 1.35 & 0 & 5.60 & 0.66 & \pm 0.64 & 0 & 2.10 & 0.66 & \pm 1.10 & 0 & 3.70 \\
\hline beta - BHC & 1.58 & \pm 2.48 & 0 & 6.40 & 2.34 & \pm 2.89 & 0 & 8.30 & 1.09 & \pm 1.20 & 0 & 4.30 \\
\hline Heptachlor & 0.20 & \pm 0.37 & 0 & 1.50 & 0.43 & \pm 0.79 & 0 & 3.00 & 0.17 & \pm 0.46 & 0 & 1.90 \\
\hline Heptachlor epoxide & 0.21 & \pm 0.48 & 0 & 1.80 & 0.25 & \pm 0.43 & 0 & 1.10 & 0.39 & \pm 0.62 & 0 & 2.00 \\
\hline Aldrin & 0.82 & \pm 1.62 & 0 & 6.50 & 0.63 & \pm 0.80 & 0 & 2.15 & 0.12 & \pm 0.24 & 0 & 0.80 \\
\hline Dieldrin & 0.44 & \pm 1.57 & 0 & 6.70 & 0.53 & \pm 0.90 & 0 & 2.50 & 0.38 & \pm 1.10 & 0 & 4.70 \\
\hline Endrin & 0.31 & \pm 0.53 & 0 & 1.90 & 0.45 & \pm 1.17 & 0 & 4.90 & 0.39 & \pm 0.64 & 0 & 2.20 \\
\hline DDT & 0.03 & \pm 0.10 & 0 & 0.40 & 0.04 & \pm 0.15 & 0 & 0.60 & 0.09 & \pm 0.20 & 0 & 0.70 \\
\hline Endosulfan I & 0.25 & \pm 0.57 & 0 & 2.40 & 0.13 & \pm 0.40 & 0 & 1.70 & 0.39 & \pm 0.96 & 0 & 4.10 \\
\hline Endosulfan 11 & 0.11 & \pm 0.25 & 0 & 0.80 & 0.38 & \pm 1.25 & 0 & 5.30 & 0.05 & \pm 0.21 & 0 & 0.90 \\
\hline Endosulfan aldehyde & 0.38 & \pm 1.24 & 0 & 5.30 & 0.27 & \pm 0.52 & 0 & 1.40 & 0.06 & \pm 0.19 & 0 & 0.70 \\
\hline Endosulfan sulfate & 0.42 & \pm 1.72 & 0 & 7.30 & 0.26 & \pm 0.99 & 0 & 4.20 & 0.02 & \pm 0.07 & 0 & 0.30 \\
\hline Phosphomethylglycine & 0.31 & \pm 0.74 & 0 & 3.10 & 0.91 & \pm 2.18 & 0 & 7.20 & 0.10 & \pm 0.18 & 0 & 0.60 \\
\hline Atrazine & 0.11 & \pm 0.21 & 0 & 0.60 & 0.73 & \pm 1.22 & 0 & 3.50 & 0.13 & \pm 0.45 & 0 & 1.90 \\
\hline Carbofuran & 0.78 & \pm 2.13 & 0 & 7.80 & 0.22 & \pm 0.92 & 0 & 3.90 & 0.32 & \pm 0.57 & 0 & 2.10 \\
\hline
\end{tabular}


Table 2 Mean concentration (ug/gww) of pesticide residues in Tilapia zilli

\begin{tabular}{|c|c|c|c|c|c|c|c|c|c|c|c|c|}
\hline \multirow{3}{*}{$\frac{\text { Pesticides }}{\text { alpha - BHC }}$} & \multicolumn{4}{|c|}{ ILLUSHI } & \multicolumn{4}{|c|}{ OGBESSE } & \multicolumn{4}{|c|}{ OWAN } \\
\hline & \multicolumn{2}{|c|}{ Mean \pm Std. D. } & \multicolumn{2}{|c|}{ Range } & \multicolumn{2}{|c|}{ Mean \pm Std. D. } & \multicolumn{2}{|c|}{ Range } & \multicolumn{2}{|c|}{ Mean \pm Std. D. } & \multicolumn{2}{|c|}{ Range } \\
\hline & 0.38 & \pm 0.90 & 0 & 3.80 & 0.88 & \pm 1.36 & 0 & 4.00 & 0.59 & \pm 1.41 & 0 & 5.50 \\
\hline gamma-BHC & 0.85 & \pm 2.04 & 0 & 8.80 & 0.13 & \pm 0.21 & 0 & 0.70 & 0.34 & \pm 0.68 & 0 & 2.40 \\
\hline beta - BHC & 0.29 & \pm 0.35 & 0 & 1.00 & 1.73 & \pm 2.57 & 0 & 8.00 & 0.77 & \pm 1.69 & 0 & 6.00 \\
\hline Heptachlor & 0.60 & \pm 0.98 & 0 & 2.90 & 0.74 & \pm 1.51 & 0 & 6.00 & 0.22 & \pm 0.46 & 0 & 1.90 \\
\hline Heptachlor epoxide & 0.12 & \pm 0.27 & 0 & 1.00 & 0.17 & \pm 0.25 & 0 & 0.60 & 0.06 & \pm 0.13 & 0 & 0.50 \\
\hline Aldrin & 0.73 & \pm 1.64 & 0 & 5.20 & 0.12 & \pm 0.24 & 0 & 0.70 & 0.13 & \pm 0.16 & 0 & 0.50 \\
\hline Dieldrin & 0.08 & \pm 0.18 & 0 & 0.60 & 0.08 & \pm 0.15 & 0 & 0.50 & 0.17 & \pm 0.24 & 0 & 0.80 \\
\hline Endrin & 0.02 & \pm 0.07 & 0 & 0.30 & 0.07 & \pm 0.16 & 0 & 0.60 & 0.06 & \pm 0.11 & 0 & 0.40 \\
\hline DDT & 0.00 & \pm 0.00 & 0 & 0.00 & 0.08 & \pm 0.23 & 0 & 0.80 & 0.03 & \pm 0.12 & 0 & 0.50 \\
\hline Endosulfan I & 0.17 & \pm 0.34 & 0 & 1.40 & 0.22 & \pm 0.32 & 0 & 1.10 & 0.19 & \pm 0.28 & 0 & 1.00 \\
\hline Endosulfan 11 & 0.03 & \pm 0.10 & 0 & 0.30 & 0.03 & \pm 0.14 & 0 & 0.60 & 0.02 & \pm 0.07 & 0 & 0.30 \\
\hline Endosulfan aldehyde & 0.12 & \pm 0.29 & 0 & 0.90 & 0.02 & \pm 0.06 & 0 & 0.20 & 0.16 & \pm 0.34 & 0 & 1.20 \\
\hline Endosulfan sulfate & 0.03 & \pm 0.12 & 0 & 0.50 & 0.16 & \pm 0.43 & 0 & 1.70 & 0.09 & \pm 0.29 & 0 & 1.20 \\
\hline Phosphomethylglycine & 0.15 & \pm 0.25 & 0 & 0.90 & 0.42 & \pm 0.89 & 0 & 3.00 & 0.54 & \pm 1.25 & 0 & 5.00 \\
\hline Atrazine & 0.18 & \pm 0.29 & 0 & 1.00 & 0.09 & \pm 0.14 & 0 & 0.40 & 0.09 & \pm 0.21 & 0 & 0.60 \\
\hline Carbofuran & 0.09 & \pm 0.24 & 0 & 0.90 & 0.02 & 0.09 & 0 & 0.40 & 0.03 & \pm 0.08 & 0 & 0.30 \\
\hline
\end{tabular}

feeders hence they are in close proximity to contaminated sediments. Mwevura et al. (2002) reported that biota in close proximity to sediments pick up residues from the sediment and this occurs by passive equilibration process through their membranes. Murano et al. (1997) and Kidwell et al. (1990) equally adds that pesticide accumulation in fish was due to their lipid content, this implies that the high lipid content in Clarias gariepinus, allows more pesticide residues tend to be trapped in their lipid stores compared to Tilapia zilli. Romanic et al., (2014) have observed a positive correlation between the lipd content of fish muscles and the concentration of organochlorine pesticides.

This study also corroborates with Deribe et al., (2014) who reports that variation in the accumulation of POPs in different fish species is attributed to trophic position, age, and fat content. The levels of pesticide contamination in fish species observerd in this study were higher

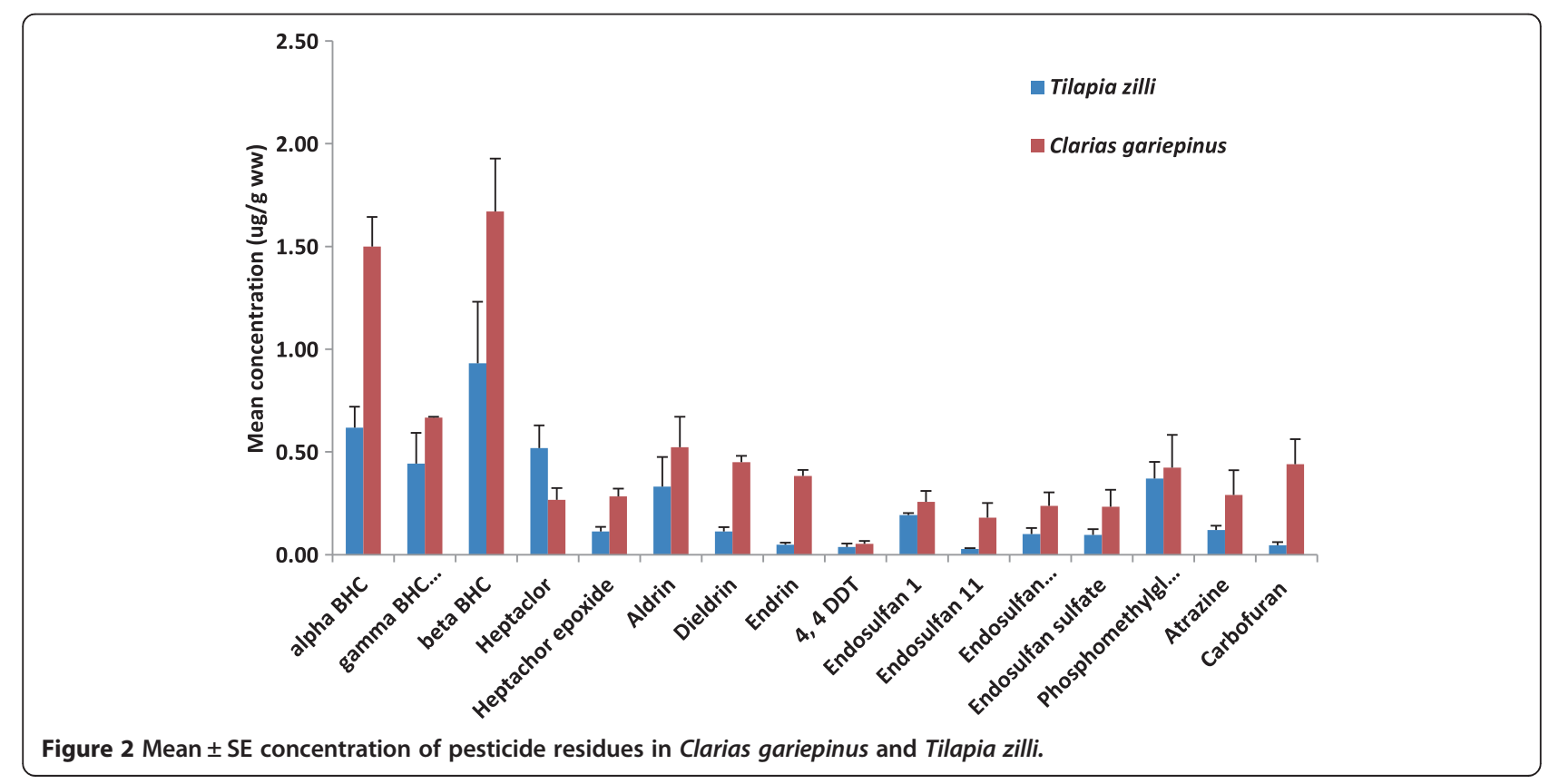




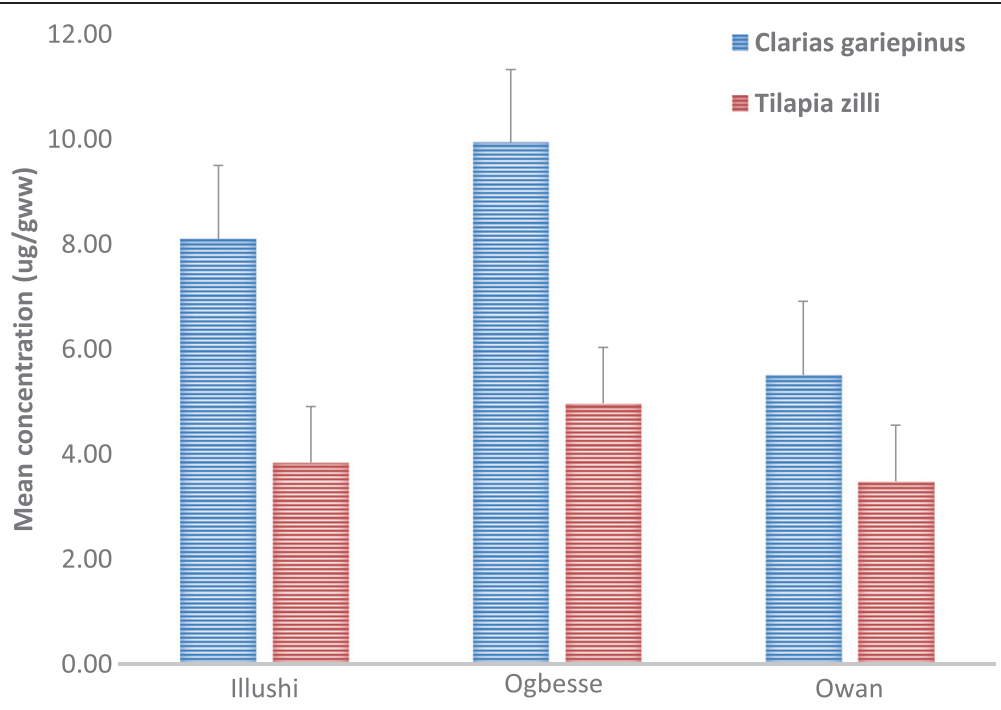

Figure 3 Mean \pm SE concentration of pesticide residues in Illushi, Ogbesse, and Owan.

than concentrations obtained in earlier studies in Nigeria. Some of these studies include: Upadhi and Wokoma (2012), Unyimadu and Udochu, (2002); Ize-Iyamu et al., (2007); Williams (2013). However concentrations observed in this study was lower than the concentrations reoprted by Ezemonye et al., (2009); Adeboyejo et al., (2011).

The presence of pesticides in fishes is a major concern because pesticides have a number of adverse effects on the aquatic organism such as reproductive impairment and suppression of the immune system (Aguilar et al., 2002), which can have long-term consequences for population viability. Furthermore, consumption of each fish species, especially species with more fat content (Clarias gariepinus), and from high trophic levels, may expose consumers to possible health hazard because the consumption of contaminated food (including fish) has been established as a major route of human exposure to pesticides and other contaminants (Biego et al., 2010; Ni et al., 2012; Barnhoorn et al., 2015).

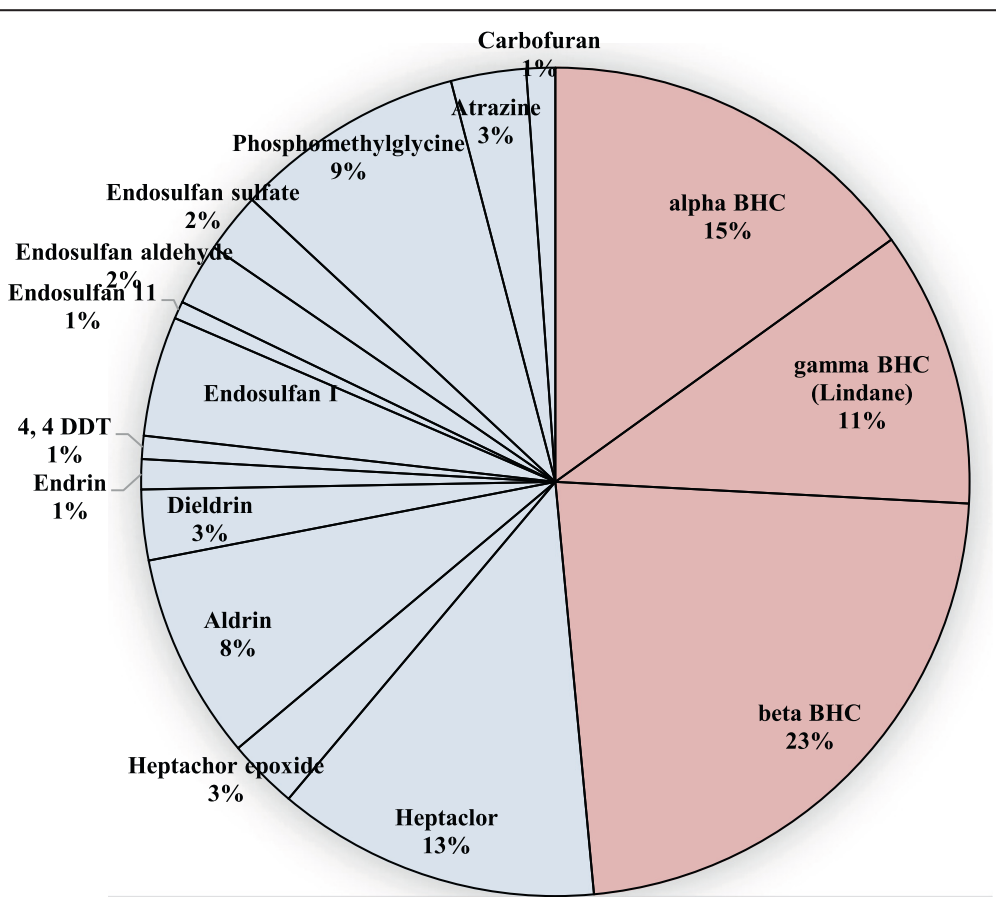

Figure 4 Percentage distribution of pesticide residues in Tilapia zillii samples. 


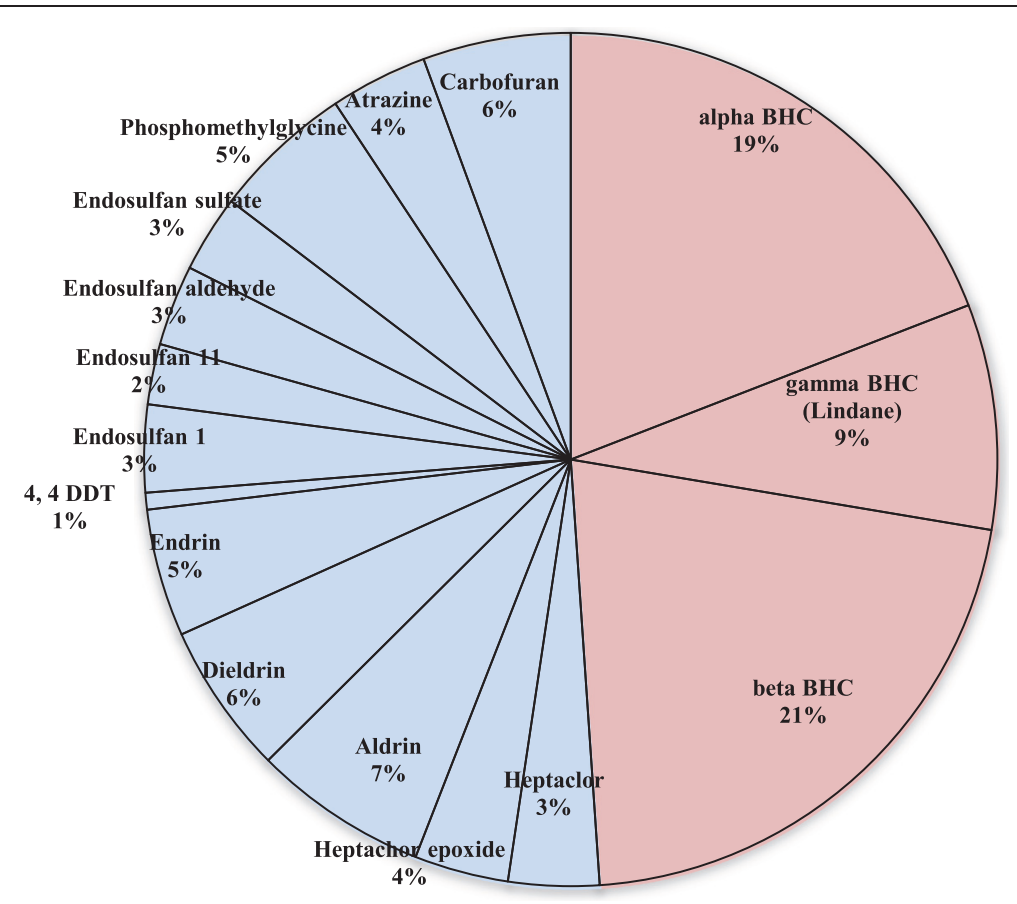

Figure 5 Percentage distribution of pesticide residues in Clarias gariepinus samples.

Health risk estimations

Assessment of the human health risk to estimate the negative and non-carcinogenic impact associated with the consumption of Clarias gariepinus and Tilapia zilli, reveals potential hazard to humans. Clarias gariepinus and Tilapia zilli are commercial aquatic products in Edo state and are a readily available and cheap source of protein for most families. Hence assessing the potential human health risk from the consumption of these fishes is an extremely important step towards public health safety. EADI for Heptachlor and Aldrin in Tilapia zilli were higher than their recommended reference dose

Table 3 Health risk assessment of pesticide residues in fishes from rivers in Edo State

\begin{tabular}{|c|c|c|c|c|c|c|c|}
\hline \multicolumn{2}{|l|}{ Pesticides } & \multicolumn{3}{|l|}{ Tilapia zilli } & \multicolumn{3}{|c|}{ Clarias gariepinus } \\
\hline & $\operatorname{Rfd}(\mu \mathrm{g} / \mathrm{kg} / \mathrm{day})$ & Residual conc & EADI & $\mathrm{HQ}$ & Residual conc & EADI & $\mathrm{HQ}$ \\
\hline alpha - BHC & 8 & 0.62 & 0.08 & 0.01 & 1.50 & 0.19 & 0.02 \\
\hline gamma - BHC & 0.3 & 0.44 & 0.06 & 0.19 & 0.67 & 0.09 & 0.29 \\
\hline beta - BHC & 8 & 0.93 & 0.12 & 0.01 & 1.67 & 0.21 & 0.03 \\
\hline Heptachlor & 5 & 0.52 & 0.07 & 0.01 & 0.27 & 0.03 & 0.01 \\
\hline Heptachlor epoxide & 0.013 & 0.11 & 0.01 & 1.09 & 0.28 & 0.04 & 2.77 \\
\hline Aldrin & 0.03 & 0.33 & 0.04 & 1.41 & 0.52 & 0.07 & 2.23 \\
\hline Dieldrin & 0.05 & 0.11 & 0.01 & 0.28 & 0.45 & 0.06 & 1.16 \\
\hline Endrin & 0.03 & 0.05 & 0.01 & 0.21 & 0.38 & 0.05 & 1.63 \\
\hline DDT & 0.5 & 0.04 & 0.01 & 0.01 & 0.05 & 0.01 & 0.01 \\
\hline Endosulfan 1 & 6 & 0.19 & 0.02 & 0.00 & 0.26 & 0.03 & 0.01 \\
\hline Endosulfan 11 & 6 & 0.03 & 0.00 & 0.00 & 0.18 & 0.02 & 0.00 \\
\hline Endosulfan aldehyde & 6 & 0.10 & 0.01 & 0.00 & 0.24 & 0.03 & 0.01 \\
\hline Endosulfan sulfate & 6 & 0.10 & 0.01 & 0.00 & 0.23 & 0.03 & 0.00 \\
\hline Phosphomethylglycine & 300 & 0.37 & 0.05 & 0.00 & 0.42 & 0.05 & 0.00 \\
\hline Atrazine & 35 & 0.12 & 0.02 & 0.00 & 0.29 & 0.04 & 0.00 \\
\hline Carbofuran & 5 & 0.05 & 0.01 & 0.00 & 0.44 & 0.06 & 0.01 \\
\hline
\end{tabular}




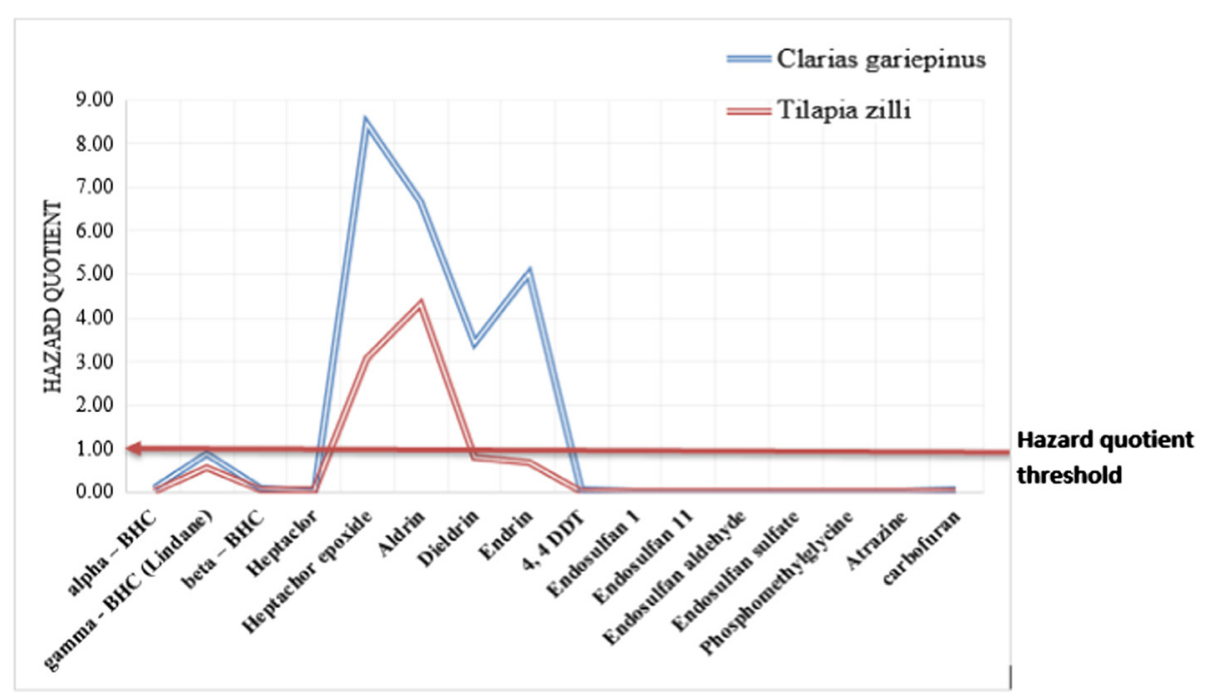

Figure 6 hazard quotient estimates for pesticide residues in fish species from rivers in Edo state.

while Hazard Quotient (HQ) values were above one (1) suggesting that the potential health risks associated with intake of Heptachlor and Aldrin, through the consumption of Tilapia zilli was high. On the other hand, EADI for Heptachlor epoxide, Endrin, Aldrin and Dieldrin in Clarias gariepinus were higher than their recommended reference dose while estimated HQ were greater than 1 suggesting potential health risk through the consumption of Clarias gariepinus. For Clarias gariepinus and Tilapia zilli the hazard index estimations showed that mixtures of organochlorine pesticides (3.863 and 9.592 respectively) were above one (1) for adult population group, suggesting that toxicity to humans from exposure could be significant. However, hazard estimates for Organophosphate, Triazine and Carbamate pesticides were below one. It has been reported that if the hazard index $>1$, the mixture has exceeded the maximum acceptable level (Tsakiris et al. 2011) and there might thus be risk. Therefore, results from this study suggest a great potential for chronic toxicity through the consumption of pesticide contaminated. The results of Human Health Risk estimations obtained from this study, conforms with studies by Darko and Akoto (2008), on pesticides in eggplant and tomatoes from Kumasi market, Sohair et al. (2013) on the Estimated Daly Intake and corresponding Health hazard of pesticide residues present in fruits from Egypt, Fianko et al. (2011) on pesticides in fish species from Densu River basin in Ghana and Andoh et al. (2013) pesticides in maize and cowpea from Ghana.

\section{Conclusion}

The concentrations of 16 pesticides residues $(\alpha \mathrm{BHC}$, $\gamma$ - BHC (lindane), $\beta$ - BHC, Heptachlor, Aldrin,
Heptachlor Epoxide, Endosulfan I, Dieldrin, Endrin, Endosulfan II, 4, 4 DDT, Endosulfan Aldehyde, Endosulfan sulfate, Atrazine, Phosphomethylglycine and Carbamate) in two common fish species in Edo State, Nigeria have been determined. From the results obtained, Clarias gariepinus had significantly higher concentrations of pesticide residues compared with Tilapia zilli. Levels of pesticide observed in both Clarias gariepinus and Tilapia zilli were lower than the recommended Reference dose except, Heptachlor epoxide, Dieldrin, Endrin and Aldrin. Risk assessment showed that Hazard quotients for Heptachlor epoxide, Dieldrin, Endrin and Aldrin were above the toxic threshold of 1 . These results indicate that human exposure (adults) to pesticides via consumption of contaminated fishes could lead to potential health risk. It also substantiate the fact that the long term accumulation of pesticide residues in the human body via dietary intake of fish is a source of concern.

This calls for more stringent regulations on the use of pesticides by farmers and also a rigorous and frequent monitoring of pesticides in various environmental matrix especially food should be encouraged so as to safe guard the health of consumers.

\section{Competing interests}

The authors declare that they have no competing interests.

\section{Authors' contributions}

L.E was the team leader of this project. He was responsible for providing the frame work and design for the overall project. O.O, was responsible for sample collection, gas chromatography instrumentation and compilation of this paper. I.T was involved in sampling for fishes, extraction and preparation of samples for further analysis, A.E was involved in sampling and the estimations of health risk and statistical analysis. E.O was also responsible for lipid normalization of samples prior to analysis. All authors read and approved the final manuscript. 


\section{Author details}

${ }^{1}$ Ecotoxicology and Environmental Forensics Laboratory, University of Benin Benin City, Edo State, Nigeria. ${ }^{2}$ National Centre for energy and environment (NCEE), University of Benin, Benin City, Edo State, Nigeria.

\section{Received: 12 December 2014 Accepted: 11 February 2015 Published online: 19 April 2015}

\section{References}

Adeboyejo OA, Clarke EO, Olarinmoye MO (2011) Organochlorine pesticides residues in water, sediments, fin and shell-fish samples from Lagos lagoon complex, Nigeria. Researcher 3:38-45

Adeyemi D, Anyakora C, Ukpo G, Adedayo A, Darko G (2011) Evaluation of the levels of organochlorine pesticide residues in water samples of Lagos Lagoon using solid phase extraction method. Journal of Environmental Chemistry and Ecotoxicology 3:160-166

Aguilar A, Borrell A, Reijnders PJH (2002) Geographical and temporal variation in levels of organochlorine contaminants in marine mammals. Mar Environ Res 53:25-52

Andoh H, Akoto O, Darko G (2013) Health Risk Assessement of Pesticide residues in maize and cowpea from Ejura, Ghana. Paper presented at 5th International Toxicology Symposium in Africa., Jointly Hosted by College of Science, Kwame Nkrumah University of Science and Technology, Ghana and Hokkaido University, Japan sponsored by Japan Society for Promotion of Science

Babu RR, Imagawa T, Tao H, Ramesh R (2005) Distribution of PCBs, HCHs and DDTs, and their ecotoxicological implications in Bay of Bengal. India Environment International 31:503-512

Barnhoorn IEJ, van Dyk JC, Genthe B, Harding WR, Wagenaar GM, Bornman MS (2015) Organochlorine pesticide levels in Clarias gariepinus from polluted freshwater impoundments in South Africa and associated human health risks. Chemosphere 120(2015):391-397

Biego GHM, Yao KD, Ezoua P, Kouadio LP (2010) Assessment of Organochlorine Pesticides Residues in Fish Sold in Abidjan Markets and Fishing Sites. African Journal of food agriculture Nutrition and development 10(3):2305-2323

Chaverri F, Soto L, Ramirez F, Bravo V (2008) Preliminary diagnosis of pesticide use in crops of rice, bananas, coffee, sugarcane, onion, melon, orange, potato, pineapple, tomato, flowers and ornamentals. Final Project Report Diagnosis pesticide use in Costa Rica. SAREC Programme: Research program in environment and health in Central America. Faculty of Earth Sciences and the Sea Regional Institute for Studies on Toxic Substances (IRET). National University. Heredia, Costa Rica. SAREC Publication: Pg 46

Darko G, Akoto O (2008) Dietary intake of organophosphorus pesticide residues through vegetables from Kumasi, Ghana. Food and Chemical Toxicology 46:3703-3706

Deribe E, Bjørn Olav R, Reidar B, Brit S, Zinabu G, Elias D, Lindis S, Ole Martin E (2014) Organochlorine Pesticides and Polychlorinated Biphenyls in Fish from Lake Awassa in the Ethiopian Rift Valley: Human Health Risks. Bull Environ Contam Toxicol (2014) 93:238-244

Ezemonye LIN, Ikpesu TO, Tongo I (2008a) Distribution of Lindane in Water, Sediment, and Fish from the Warri River of the Niger Delta. Nigeria Journal of Arh Hig Toksikol 59:261-270

Ezemonye LIN, Ikpesu TO, Tongo I (2008b) Distribution of Diazinon in Water, Sediment and Fish from Warri River, Niger Delta, Nigeria. Jordan J Biol Sci 1 (2):77-83

Ezemonye LIN, Ikpesu TO, Tongo I (2009) Distribution of Propoxur in water, sediment and fish from Warri River, Nigeria Delta, Nigeria. Turkish Journal of Biochemistry 34(3):121-127

FAO (2011) Fishery and Aquaculture Statistics. 2009. Statistics and Information Service of the Fisheries and Aquaculture Department/Service. 2009. Rome/ Roma, FAO. 2011., p 78

Fianko RJ, Augustine D, Samuel TL, Paul OY, Eric TG, Theodosia A, Augustine F (2011) Health Risk Associated with Pesticide Contamination of Fish from the Densu River Basin in Ghana. Journal of Environmental Protection 2:115-123

Gavor S, Martin Kwasi A, Osei A (2013) Assessment of Health Risk of Pesticide Residues in Selected Vegetables from Kumasi Central Market. Paper presented at 5th International Toxicology Symposium in Africa. Jointly Hosted by College of Science, Kwame Nkrumah University of Science and Technology. Japan sponsored by Japan Society for Promotion of Science, Ghana and Hokkaido University, Hokkaido University publication

Hoffman DJ, Rattner BA, Burton GA, Cairns J (2003) Handbook of Ecotoxicology, 2nd edn. Lewis Publishers, CRC Press, Boca Raton, FL
Hossain MS, Hossain MA, Rahman MA, Islam MM, Rahman MA, Adyel TM (2013) Health risk assessment of pesticide residues via dietary intake of market vegetables from Dhaka, Bangladesh. Foods 2013(2):64-75

Ize-lyamu OK, Asia IO, Egwakhide PA (2007) Concentrations of residues from organochlorine pesticide in water and fish from some rivers in Edo State Nigeria. Int J Phys Sci 2(9):237-241

Jiang QT, Lee TKM, Chen K, Wong HL, Zheng JS, Giesy JP, Lo KKW, Yamashita N, Lam PKS (2005) Human health risk assessment of organochlorines associated with fish consumption in a coastal city in China. Environ Pollut 136:155-165

Kidwell JM, Phillips L, Birchard GF (1990) Comparative analysis of contaminants levels in bottom feeding and predatory fish using the national contaminants biomonitoring program data. Bull Contam Tox 55(6):919-923

Liu CJ, Men WJ, Liu YJ (2002) The Pollution of Pesticides in Soils and its Bioremediation. System Sciences and Comprehensive Studies in Agriculture 18(4):295-297

Maurano FM, Guida G, Melluso GS (1997) Accumulation of Pesticide Residues in Fishes and Sediments in the River Sele (South Italy). Journal of Preventive Medicine and Hygiene 38:3-4

Murty AS (1986) Toxicity of pesticides to fish Volume II. LRC Press, Boca Roton F. L

Mwevura H, Othman CO, George LM (2002) Organochlorine Pesticide Residues in Edible Biota from the Coastal Area of Dar es Salaam City. Pesticide Residues In Coastal Dar Western Indian Ocean. J Mar Sci 1(1):91-96

Ni H-G, Chao D, Shao-You L, Xiao-Ling Y, Sojinu Olatunbosun S (2012) Food as a main route of adult exposure to PBDEs in Shenzhen, China. Science of the Total Environment 437(2012):10-14

Okeniyia SO, Eqwikhide PA, Akporhonore EE, Obazed El (2009) Distribution of organochlorine and polychlorinated pesticides residues in water bodies of some rivers in northern Nigeria. EJEAFche 8(11):1269-1274

Okoya AA, Ogunfowokan AO, Asubiojo OI, Torto N (2013) Organochlorine Pesticide Residues in Sediments and Waters from Cocoa Producing Areas of Ondo State. International Scholarly Research Network (ISRN) Soil Science, Southwestern Nigeria

Olatunbosun SS, Sojinu O, Sonibare E, Eddy O, Zeng Y (2011) Occurrence of Organochlorine Pesticides (OCPs) in Surface Sediments of the Niger Delta, Nigeria. Journal of Applied Sciences Research 7(8):1299-1305

Pardío V, Martínez D, Flores A, Romero D, Suárez V, López K, Uscanga R (2012) Human health risk of dietary intake of organochlorine pesticide residues in bovine meat and tissues from Veracruz, México. Food Chemistry 135:1873-1893

Randall RC, Young DR, Lee H II, Echols SF (1998) Lipid methodology and pollutant normalization relationships for neutral nonpolar organic pollutants. Environ Toxicol Chem 17(5):788-791

Romanic SH, Herceg HD, Lazar B, Klincic D, Mackelworth P, Fortuna CM (2014) Organochlorine contaminants in tissues of common bottlenose dolphins Tursiopsruncatus from the northeastern part of the Adriatic Sea. Environmental toxicology and pharmacology 38(2014):469-479

Sohair AG, Mohsen A, Ayoub M, Amer MA, Wasfi MT (2013) Dietary Intake of Pesticide Residues in some Egyptian Fruits. Journal of Applied Sciences Research 9(1):965-973

Steinwandter H (1992) Development of Microextraction methods in residue analysis. In: Cairns T, Sherma J (eds) Emerging strategies for pesticide analysis. CRC, Boca Raton, FL, pp 3-50

Tsakiris loannis N, Toutoudaki M, Kokkinakis M, Paraskevi M, Tsatsakis AM (2011) A Risk Assessment Study of Greek Population Dietary Chronic Exposure to Pesticide Residues in Fruits, Vegetables and Olive Oil in Pesticides Formulations, Effects, Fate. Stoytcheva M (Ed). ISBN: 978- 953-307-532-7

United States Environmental Protection Agency (USEPA) (1998) Guidelines for Ecological Risk Assessment. Washington, US: EPA, Report No. EPA/630/ R-95/002F

United States Environmental Protection Agency (USEPA) (2004) Guidelines for Water Reuse. EPA/625/R-04/108.US EPA. CampDresser \& McKee Inc, Washington, DC

United States Environmental Protection Agency (USEPA) (2006) Guidance for assessing Chemical contaminant data foruse in fish advisories, 2, 231-253

Unyimadu JP, Udochu A (2002) Comparative Studies of Organochlorine and PCBs in Fish from the Lagos Lagoon. River Elber Saar. Journal of Agricultural Biotechnology: Environmental 4(1-2):14-17

Upadhi F, Wokoma OAF (2012) Examination of Some Pesticide Residues in Surface Water, Sediment and Fish Tissue of Elechi Creek, Niger Delta. Nigeria Research Journal of Environmental and Earth Sciences 4(11):939-944

WHO (World Health Organization) (1997) Guidelines for predicting dietary intake of pesticide residues (revised) global environmental programme (GEMS/ Food) in collaboration with Codex Committee on pesticide residues. Programme of Food Safety and Food Aid 1-44 
Williams BA (2013) Levels and distribution of chlorinated pesticide residues in water and sediments of Tarkwa Bay, Lagos Lagoon. Journal of Research in Environmental Science and Toxicology 2(1):1-8

Yohannes YB, lkenaka Y, Nakayama SMM, Ishizuka M (2013) Organochlorines pesticides in fish species from Lake Ziway, Ethiopa; Association with Tropic Level and Human Health Risk Assessment., Paper presented at 5th International Toxicology Symposium in Africa. Jointly Hosted by College of Science, Kwame Nkrumah University of Science and Technology, Ghana and Hokkaido University, Japan sponsored by Japan Society for Promotion of Science. Hokkaido University publication

Submit your manuscript to a SpringerOpen ${ }^{\odot}$ journal and benefit from:

- Convenient online submission

- Rigorous peer review

- Immediate publication on acceptance

Open access: articles freely available online

- High visibility within the field

- Retaining the copyright to your article

Submit your next manuscript at $>$ springeropen.com 